\title{
PECULIARITIES OF MEDICAL AND PSYCHOLOGICAL REHABILITATION OF PARTICIPANTS OF MILITARY ACTIONS WITH POSTCONCUSSIONAL SYNDROME
}

\author{
Pronoza-Steblyuk $K$. \\ State Institution "Academician A. Romadanov Institute of Neurosurgery \\ of the National Academy of Medical Sciences of Ukraine", Ukraine \\ https://doi.org/10.35339/ic.7.1.45-48
}

\begin{abstract}
Forty-eight families of veterans with post-concussion syndrome were directed for medical and psychological rehabilitation. At the beginning of the rehabilitation course, personal psychological problems (by anonymous survey and testing) were recognized in 42 veterans and 44 veterans' wives. Problems related to family relationships were identified in 39 families. The weekly courses included: the physical component of rehabilitation, psychological (psychotherapeutic) rehabilitation component and measures conditionally related to microsocial rehabilitation.

The applied psychological assistance methods in combination with the physical and social components of the program led to an improvement in the personal psycho-emotional state of $96 \%$ of participants. Improvement of family understanding and psychological microclimate was noted by $100 \%$ of families. $60 \%$ of families expressed a desire to continue working with a psychologist. Based on the experience gained, recommendations have been made to improve mutual understanding in families.

The use of these methods of intra-family psychological self-regulation will contribute to the normalization of relations, reduction of the clinical physical and mental effects of contusion, and improvement of the resocialization of veterans.
\end{abstract}

Key words: post-concussion syndrome, medical and psychological rehabilitation, family psychotherapy.

\section{Introduction}

The urgency of the problem: Traumatic brain injuries take a significant place in combat injuries. This is noted by foreign researchers and confirms the experience of our compatriots according to the results of the military actions in the Donbass region [1].

Neurotrauma has its own peculiarities that necessitate a special approach to first-aid dressing, treatment and rehabilitation [2]. Postconcussional syndrome in modern conditions is caused by the high specific gravity of mild traumatic brain injury (according to the NATO terminology - mild

Corresponding Author:

Katerina Pronoza-Steblyuk - MD, State Institution

"Academician A. Romadanov Institute

of Neurosurgery of the National Academy

of Medical Sciences of Ukraine", Kyiv, Ukraine.

E-mail:pronoza@ukr.net traumatic brain injury, mTBI) in the structure of combat trauma among combatants in eastern Ukraine. This is due to the fact that today more than $80 \%$ of combat damage is a mine-explosive injury, and a third of injuries are injuries of the head. In its turn, in the structure of head injuries, mTBI is about $83 \%[3,4]$.

Mild traumatic brain injury, including concussion and brain injury of a mild degree according to terminology familiar to the Ukrainian medical community, in the absence of proper treatment and rehabilitation, in about one third of cases, leads to long-term complications in the form of postconcussional syndrome, which manifests itself mainly as disorders of the autonomic nervous system and disorders in the psycho-emotional sphere [5].

Combination of organic pathology with changes in the psycho-emotional sphere, aggravation of somatic and neuro-vegetative 
symptoms by the effects of combat mental trauma, adaptation disorders (including psycho-social) and difficulty of reintegration, complications in the form of various addictions (alcohol, other substances, gambling), require the search and application of comprehensive measures of therapeutic and rehabilitation impact, among which an important place is occupied by medical and psychological rehabilitation [7].

At the same time, the lack of awareness of the peculiarities of the disease course, the attempt to organize medico-psychological rehabilitation of war veterans in homogeneous closed groups does not allow patients to escape from a closed circle, to fully readapt to a normal peaceful life, to resocialize [8]. Each time, during such "rehabilitation" there is a re-traumatization of memories, the restoration of the "heroic" phase, the deepening of intrusive memories, which fits well with the background aggravated by alcohol consumption in the environment of similar veterans [9].

\section{Purposes, subject and methods}

2.1. The purpose of the work was development and testing of a comprehensive program of medical and psychological rehabilitation of combatants with postconcussional syndrome.

\subsection{Subjects and methods}

In order to achieve the set goal, 48 families of combatants diagnosed with F 07.2 postconcussional syndrome were surveyed during 2017-2019 complying with bioethics principles.

The following survey methods were used in the study: clinical and psychological; psychodiagnostic using the post-trauma stress disorder symptoms Self-Assessment Scale PCL; Traumatic Impact Scale (IES-R): Methods for Studying Styles of Coping Behaviors (Copying Methods (adapted by T.A. Kryukova, 2002), K. Thomas's Methods for "Determining Conflict Management Methods" edited by N.V. Gryshyna (by D.Y. Raygorodsky, 2002) [10].

The symptoms of the postconcussional syndrome were evaluated by the Cicerone Questionnaire (1995) [11] - assessment of the symptoms of the present time, the study of the state of vegetative regulation was carried out by completing the questionnaire for subjective evaluation of dystonia [12].

The mathematical and statistical processing of the results of the study was carried out using specialized software packages (Statistica 6.0, MS Excel) using the Student's t-test method.

Conflict of interest. There is no conflict of interests.

\section{The results and discussion}

As shown by the results of the study, in the examined families of veterans with postconcussional syndrome, family dysfunction was characterized by impaired interpersonal interaction between spouses $(82.3 \%)$, psychosocial maladaptation (64.1\%); breach of interpersonal relationships $(86.2 \%)$; deformation of family interaction $(72.3 \%)$.

In the course of work, we developed and tested a system of psychosocial rehabilitation, which included: physical component of rehabilitation (hiking and walking, mountain climbing, training on the simulators, sports games, visits to the salt room), psychological (psychotherapeutic) component of rehabilitation (individual and group work with a psychologist, art therapy using design techniques, training in psychological recovery and the acquisition of skills of resilience [8] and measures related to microsocial readaptation.

At the beginning of the rehabilitation course, 42 veterans and 44 veteran wives found personal psychological problems (according to an anonymous survey and testing). In 39 families, problems related to the family were identified.

The methods of psychological assistance used in combination with the physical and social components of the program led to an improvement in the personal psycho-emotional state of $96 \%$ of the program participants. Improvement of family understanding and psychological microclimate was noted in $100 \%$ of families. $60 \%$ of families showed the desire to continue working with a psychologist. It is the teaching of the family to live with the consequences of the past, "bringing peace to war, not war to peace", which became the core of the program of long-term psychological support and psychological self-regulation.

As a result of the work, a program of intrafamilial support for veterans with postconcussional syndrome was developed, which included the following modules:

I. Informational module (Understanding) was aimed at filling the information deficit of knowledge about etiopathogenesis and clinical manifestations of postconcussional syndrome, the need for pharmacotherapy, the importance of psychosocial rehabilitation; reducing the level of stigmatization and self-stigmatization.

II. Family support. Family response should be active at all stages (return, treatment, rehabilitation, etc.), family members should learn 
not only weaknesses, but also new resources and strength of the victim (the opportunity to be a volunteer, if not to serve; support of brothers, etc.). All family processes should be present and future oriented, but it must be remembered that there are effective survival strategies that have helped the family in the past and are aimed at creating and developing hope and positive expectations, encouraging and supporting new forms of behavior, encouraging concentration attention and finding a solution, not the problem itself. The family should keep in mind the health orientation and that changes are due to strengthening.

The main compatible goal of the family is to regain the ability to control the situation, focus on quality of life, not pathology.

III. Warning. Unfortunately, in conditions when a person can no longer perform the functions that he performed before the trauma, a feeling of needlessness, neglect, and futility of his own existence develops. It is very important to understand that a constant depressed state, a sense of a shorted future, an inability to "find yourself" is a possible prerequisite for alcohol abuse and suicidal thoughts. Especially in the early stages of adapting to the new state, it is important to observe and share the views of all family members. Avoiding direct confrontation, joint needs identification, family support to restore decision-making ability (to understand the purpose, nature and impact of actions and actions management), development of partnerships in a joint way to recovery, development of health promotion behaviors and achievement of functional independence through various current measures, elimination of simultaneous life factors of stress.

IV. External involvement. Engaging with consent in social support networks - community, veteran, to abstract from the severe and negative manifestations of trauma is the key to a healthy future of a veteran and a family in general.

As the results of dynamic observation showed, stable positive dynamics of psychological state with statistically significant reduction of posttrauma stress disorder symptoms (76.9\%), reduction of family conflict (71.4\% of families), harmonization of marital relations $(66.2 \%$ of families), positive transformation of the coping strategy $(56.6 \%)$ - decision-oriented and social distraction and activation of adaptive forms of coping ( $70.5 \%$ of families) focused on social support, and a political approach to solving problems were noted against the background of the proposed system of medical and psychological rehabilitation in the examined families.

The data obtained of the complex of medical and psychological rehabilitation program of combatants correlate with the data of domestic researchers devoted to the development directions of prevention and algorithms for the formation of personalized programs of therapy and rehabilitation of combatants with traumatic stress disorder with $[13,14]$, he identification of specific target symptoms, is critically important for the recovering of the mental health, living conditions of combatants, and actually medical rehabilitation intervention complex includes: combination of psychotherapy and psychopharmatherapy. However, the proposed system of personalized medico-psychological rehabilitation of combatants with post-concussion syndrome, is new one, as well as, using in psychosocial rehabilitation complex with a particular focus for intimate family support of veterans.

\section{Conclusions}

Thus, the obtained results made it possible to substantiate the feasibility of the proposed system of medical and psychological rehabilitation of combatants with postconcussional syndrome.

\section{References}

1. Danyk Yu. H., Druz O. V., Chernenko I. O.(2016). Formuvannia syndromiv viin ta yikh osoblyvosti. Journal of Education, Health and Sport, (6/11), 77-89.

2. Hesdorffer, D. C., Rauch, S. L. Tamminga, C. A. (2009). Long-term Psychiatric Outcomes Following Traumatic Brain Injury: A Review of the Literature. J Head Trauma Rehabil, (24/6), 452-459.

3. Voloshyn P. V., Maruta N. O., Shestopalova L. F. [ta in.]. (2014). Diahnostyka, terapiia ta profilaktyka medyko-psykholohichnykh naslidkiv boiovykh dii v suchasnykh umovakh : metodychni rekomendatsii . Kh.: DU "Instytut nevrolohii psykhiatrii ta narkolohii NAMN Ukrainy", 80.

4. Cicerone K.D. (1995). Base of Neurobehavioral Symptom Inventory (NSI)// Journal of Head Trauma Rehabilitation, (10/3), 1-17.

5. Veina A. M. (2000). Vehetatyvnye rasstroistva: Klynyka, lechenye, dyahnostyka. Moskov. Medytsynskoe ynformatsyonnoe ahentstvo, 752. 
6. Druz O. B., Syropiatov O. H., Badiuk M. L. [ta in.]. (2015). Udoskonalennia likuvannia ta reabilitatsii viis ko vo sluzhbov tsiv Zbroinykh Syl Ukrainy iz boiovoiu psykhichnoiu travmoiu : metodychni rekomendatsii, Kyiv.: "MP Lesia", 52.

7. Maruta N.O., Zavorotnyi V.I. (2018). Pryntsypы reabylytatsyy voennosluzhashchykh s razlychnыmy varyantamy posttravmatycheskoho stressovoho rasstroistva. Ukrainskyi visnyk psykhonevrolohii, (26, 3/96), 33-38.

8. Chaban O. S., Frankova Y. A. (2015). Sovremennue tendentsyy v dyahnostyke y lechenyy posttravmaty ches koho stressovoho ras st roistva. Neiro News, $(2 / 66), 8-18$.

9. Bohomolets O. V., Pinchuk I. Ya., Druz O. V. [ta in.]. (2014). Optymizatsiia pidkhodiv do nadannia psykhiatrychnoi dopomohy vidpovidno do suchasnykh potreb uchasnykiv boiovykh dii : metodychni rekomendatsii. Kyiv, 50.

10. PTSD: National Center for PTSD: https://www.ptsd.va.gov

11. Weiss, D. S., Marmar, C. R., Wilson J., Keane T. M. (Eds.). (1996). The Impact of Event Scale. Assessing psychological trauma and PTSD New York: Guilford. 399-411.

12. Stebliuk V., Pronoza-Stebliuk K. (2018). Travma ta travmoterapiia: istoriia ta sohodennia. Ukrainskyi visnyk psykhonevrolohii. (26, 4 /97), 83-86.

13. Druz O. V., Hrynevych Yu. H., Chernenko I. O. (2018). Kompleks metodiv, protsedury ta alhorytm psykhoterapii v strukturi dyferentsiiovanykh prohram psykhosotsialnoi reabilitatsii staniv dezadaptatsii u uchasnykiv lokalnykh boiovykh dii. European multi science journal, 22, 5-11.

14. Chernenko I. O. (2018). Psykhofarmakoterapiia v strukturi dyferentsiiovanykh indyvidualizovanykh prohram psykhosotsialnoi reabilitatsii staniv dezadaptatsii u uchasnykiv lokalnykh boiovykh dii. Arkhiv psykhiatrii, 95, 182-186.

Received: 01-Jun-2019

Accepted: 21-Jan-2020 